Tér és Társadalom 1. évf. 1987/1

1987. 1. évf. 1. sz. pp. 17-30.

BÖHM ANTAL:

\title{
A HELYI HATALOM ÉS A LAKOSSÁGI RESZVÉTEL ESÉLYEI
}

Mostanában egyre több szó esik a lakossági részvételröl, mint ami fontos szerepet játszik egy-egy település lakópolgárainak közérzetében, s ennélfogva megbecsülendర̆, fejlesztendő dimenziója a helyi társadalom mindennapi életének. Nem kevésbé fontos azonban az a kérdés sem, hogy e részvételnek milyen feltételrendszere alakult ki településeink hatalmi szerkezetében, milyen szabályok, garanciák, s milyen lakossági igények motiválják müködését. E kérdések megválaszolásához ismételten meg kell vizsgálnunk a helyi hatalom mechanizmusait, szerveződési módjait, gazdasági és társadalmi körülményeit, mindenekelött azt, hol, milyen összefüggés-rendszerben kell keresnünk a helyi hatalmat. (Azért ismételtem, mert néhányszor már vizsgáltuk, pontosabban e kérdések a helyi társadalom problémáival foglalkozó kutatócsoportunk vitáiban kezdettôl fogva jelen vannak. Ezzel kapcsolatban talán elegendő Gombár Csaba: A helyi hatalom hermenetuikája, valamint Pál László: Kisérlet a helyi hatalom dimenziójának megragadására című tanulmányára hivatkozni. Helyi társadalom I-II. Társadalomtudományi Intézet.)

\section{A helyi hatalom "koordinátái"}

Jelen esetben tehát nem a helyi hatalom funkcióira és funkcionálására koncentrálunk, hanem arra, hogy a társadalomszerkezet hatalmi mechanizmusaiban hol, $s$ milyen súlypontok körül szerveződik és müködik, azaz milyen területen helyezhetó el. (Természetesen ennél nem kevésbé fontos az sem, hogy miben áll a helyi hatalom mindez azonban meghaladja e tanulmány kereteit.)

Amennyiben sematikusan ábrázoljuk, a helyi hatalom érvényesülésének terrénuma - nézetem szerint - egy olyan koordináta-rendszerben helyezkedik el, amelynek tengelyei: a centrum és a lokalitás, illetve a munkahely és a lakóhely. Mellesleg ez a mozgástér egybeesik mindennapi életünk szerveződési kereteivel is. Ez a rendszer - első ránézésre is felismerhetően - idők során erősen deformálódott, s napjainkra müködésében a centrumnak és a munkahelynek a túlsúlya vált meghatározóvá. E túlsúly természetesen mindkét esetben évszázados tradiciókra vezethető vissza.

A centrum és a lokalitás viszonylatában az állam túlnyomó hatalmát az abszolút monarchia kialakulásának körülményeiból és idejéből származtathatjuk, ugyanis 'ényegében ekkor „határolódott” el az állam az egvénektól és a lokális közösségektöl végérvényesen. E folyamat felismerési és átélési módjáról SZEKFÚ GYULA így ír: 
„Száz esztendővel ezelött csak a legélesebb elmével birók sejtették meg azt, amit ma minden ember tud és saját magán napról napra, sőt a nap minden órájában újra tapasztalni kénytelen, azt, hogy a politikának igazában csak egyetlen nagy problémája van: az állam elhatárolása az egyéntól és az egyénekból álló társadalomtól." (SZEKFỦ GY. 1983. 35. p.)

A polgári társadalomfejlódés, a demokratikus állameszmény és intézményrendszer jelenthetett csak alternatívát az abszolút monarchiával szemben. A társadalomfejlódésnek ez a vonala azonban a magyar és általában a kelet-európai térség társadalmai számára az ismert okok következtében nem realizálódott, a polgári fejlődés retardált maradt, a polgári társdalom és a politikai állam kapcsolatában nem alakult ki a nyugat-európai fejlödésnek megfelelö demokratikus intézményrendszer; etatizmus és erős centralizmus jellemezte a társadalmi létet. Következésképpen hiányzott a társadaIom életébōl - többek közt - a társadalomszervező hatású egyesületi tevékenység, „sem a vezetó réteg, sem pedig a falusi nép nem rendelkezett életképes szervezetekkel, a lakosság tökéletesen atomizálva volt, s e szervetlen és szervezetlen tömeg fölé borult egyetlen védöponyva gyanánt az államhatalom. $\mathrm{S}$ amikor ezt a ponyvát egy pillanatra elfútta a történelem szele, a nemzet ott áliott védtelenúl a zimankóban." (SZEKFÜ GY. 1983, 28. p.)

Természetesen nemcsak a nemzeti létet, hanem az egyéni magatartás lehetőségeit és formáit is meghatározta ez a hatalmi szerkezet. TÁRKÁNY SZÚCS ERNÓ a jogi népszokásokat vizsgálva igen szemléletes ábrán mutatja be, ahogy a XVIII. századtól az 1940-es évekig milyen mértékben kerültek elótérbe az állami szabályok, s szorultak vissza a hagyományok, lokális elöírások, szokások, $s$ miként befolyásolták e változások az egyén jogtudatát. (TÁRKÁNY SZÚCS E. 1981.40. p.) „Amikor pedig az állami szabályok hatékonnyá válása, térnyerése a hagyományos megoldásokat háttérbe szorította, a társadalmi szinten súrúsödó feszültségek az affinitás törvényei szerint újabb, most már domináló variánsok megszünését érték el. A szokás tehát nemcsak alkalmazkodást, hanem újitást is jelenthetett, régi és új pedig sokáig társadalmi feszültségeket rejtó módon állhatott szemben egymással." (TÁRKÁNY SZÜCS E. 1981, 38. p.) Ezek a jogi népszokások pedig mégiscsak mủködtek, igaz, nem az állam engedélyével, hanem attól elkülönülten, mert a „társadalom különbözó, kisebb-nagyobb csoportjai belső autonómiảjuknál fogva, életviszonyaik rendezésére alkalmasabbnak találták, mint az állami, egyházi vagy egykor a földesúri előirásokat." (TÁRKÁNY SZÜCS E. 1981, 42. p.)

A lakóhely-munkahely viszonylatában a lakóhely elsódlegessége tehát tradicionális, ez határozta meg a személyek társadalmi helyzetét, státusát, tevékenységi körét, s végsó soron társadalmi lehetőségeit, esélyeit is. „Mindenki lakott valahol, tartozott valamilyen településhez, és ennek jogállása, a rá meghatározott vagy az általa megállapított szabályok, az emberek közötti konfliktusok feloldására vonatkozó eljárási és rendezó elvek, a kötelezettségek (adó, úrbéri szolgáltatások, katonai terhek stb.) kiha. tottak a kötelékébe tartozó személyekre is. A lakóhelyhez való tartozás folytán elvárták a személytól a kötelességek teljesítését, a szokảsok megtartását, a szolidaritást jóban-rosszban." TÁRKÁNY SZÜCS E. 1981, 51. p.) Közösségi illetöségét a lakóhelyi kötöttségeit csak a lakóhely feladásával, a lakóheiytôl való elszakadással változ tathatta meg az adott személy (például a szökött jobbágyok). 
A polgári fejlődés, az ipar és az urbanizáció tömegessé tette a kiszakadás lehetôségeit, egyben átrendezte a lakóhely és a munkahely tradicionális kapcsolatát azzal, hogy mindinkább a munkahelyi feltételeknek rendelte alá az egyént, a munkavállalót. Különösen a mezőgazdaságból kiszoruló, városokba meneküló nincstelenek, agrárproletárok, alkalmi munkások kerültek abba a helyzetbe, amelynek egyetlen dimenziójává a megélhetés és a fennmaradás vált. Az iparosodás és az urbanizáció - bár megkésetten és ellentmondásosan - Kelet-Európában is megindult a XIX. század második felében, s nyomában a „rural exodus”. A folyamat nagyságára jellemző, hogy a főváros lakossága

$\begin{array}{lll}1880-1890 & \text { között } & 135.000 \text { fövel } \\ 1890-1900 & & 301.000 \\ 1900-1910 & & 251.000 \\ 1910-1920 & & 122.000 \\ 1920-1930 & 210.000 \\ 1930-1941 & 270.000 \text { fóvel }\end{array}$

dás tekintélyes arányát a beköltözők, falvakról elvándorlók alkották. (RÁNKI GY. 1983. pp. 257-258.) A lakóhely tradíciói, a kötöttséget és a személy életét szabályozó szokások, magatartási módok, értékek helyébe a munkahely és a munkaszerzés kényszere, kötöttsége egyszersmind értéke lépett nagy tömegek számára. A munkához jutás korlátozottsága, a periodikusan fölerōsödő munkanélküliség pedig még inkább megnövel te a munkahely szerepét a lakóhely rovására.

A centrum és a munkahely túlsúlya tehát a magyar társadalom fejlödésében évszázados hagyományokra tekinthet vissza. A helyi hatalom múködése szempontjából e markáns tényeken kivül még azt is figyelembe kell vennünk, hogy mindez egybeesett a politikai elméletben és gyakorlatban, valamint az irányitás minden szintjén megnyilvánuló paternalista rendszer kiépülésével. Ami a hatalmi vonatkozásait illeti, a paternalista hagyományok is mélyen visszanyúlnak a rendi társadalomba. Már a centralisták fölfigyeltek a földesúr "atyáskodó pártfogására" és patriarchális uralmára. (SZEKFÜ Gy. 1983, 18. p.) A "várurak" uralma ennél fogva könnyen vált behelyettesíthetővé a későbbiekben a "gyárurak uralmával” - a szójáték szintén Szekfütöl származik. (i.m. 25.) - miközben az uralom jelzói (jóságos, gondoskodó, atyai) változatlanok maradhattak. Mindezt az egyes üzemek, gyárak szociális juttatásai, kedvezményei természetesen még inkább fölerősítették. A magyar gyáripar szervezeti fölépítését, belsó hierarchiáját, a privilégiumok juttatását, a hatalmi funkciók és hatáskörök "leosztását" a gondoskodás, az érdekek és áldozatvállalás kölcsönössége hatotta át.

$\mathrm{Az}$ ipari szervezetek a föhatalom struktúrájának és ideológiájának a mintájára szerveződtek, amely - szintén természetesen - jóságos volt és gondoskodó, omnipotens és providenciảlis, népszeretó és - mint olyan - érzékeny, moralizáló, s az elosztá. si viszonyaiban müködő́ redisztribúciót is - úgymond - nemzeti és össztársadalmi érdekek határozták meg. Pedig voltaképpen: „a jótékonyság és az áldozatkészség - netán ószintén gondolt pózában - a hatalmi tevékenység úgy jelenik meg, mint népért való gondoskodás, mint népszeretet, de amely mindenkor örizkedik a nép demokratikus uralmi befolyásának érvényesülésétól." (GOMBÁR CS. 1980, 134. p.)

A paternalista államhatalomnak és üzemszervezetnek rendkivül fontos következménye az, hogy egyedül az alattvalói tudat- és magatartási formák iránt toleránsak, 
s minden más attitüdöt, véleményt vagy megnyilvánulást eleve kizárnak, mint amelyek érdemtelenek a jóságos gondoskodásra.

A szocialista átalakulás, s a megelőzó népi demokratikus korszak mindkét vonatkozásban gyökeres fordulatot ígért. A forradalmi változások bekövetkeztek, csakhogy a hatalmi struktúrában az 50-es évek elején újabb eröteljes centralizáció zajlott le. A gyors gazdaság- és társadalomfejlödés igénye felerősítette a központosítás ideológiáját és gyakorlatát. „Rendkivüli módon centralizált, hierarchikusan felépitett politikai szerkezet alakult ki, amelynek nem volt tényleges kontrollja, sőt, az intézményes ellenörzés és korrekció társadalmi bázisa felbomlott, hiszen az államositások és szövetkezetesítések következtében megszüntek az önálló polgári és kispolgári egzisztenciák, valamilyen értelemben mindenki állami alkalmazottá, és minden legális szervezet a párt transzmissziós szervévé vált." - mondja HANÁK PÉTER. (HANÁK P. 1982, 115. p.) A vezetô réteg támogatta a szervezett és felülröl irányított „spontán" tömegmozgalmakat, "mindez azonban az ötvenes évek első felében csak álközéletet, álrészvételt, irányított és szabályozott politikai mozgalmat, és csupán alattvalói politikai kultúrát eredményezett, amely inkább elidegenitette az embereket a politikától, nemhogy kimüvelte volna őket." (HANẢK P. 1982, 115. p.) Vagyis az igért és remélt áttörés, a tényleges demokratizálódás nem következett be.

A munkaszervezetekben hasonló folyamatok játszódtak le; ugyanis azokban is kisérlet történt a paternalizmus felszámolására. E törekvések jegyében 1945 után megszüntették a privilegizált helyzetü munkásrétegek monopóliumait, a munkáselit, a munkásarisztokrácia a múvezetökkel együtt elveszitette korábbi pozícióit, a munkaszervezeti hierarchiából adódó hatalmi szerepeit, megtörtént a kiegyenlítés a munkásság körében - mindez azonban alacsonyabb szintre, lefelé. (KULCSÁR K. 1985.) Az alacsonyabb szintü nivellálás természetesen nem törte át a paternalizmust és nem szüntette meg az alattvalói mentalitást. Ellenkezőleg, a korábban privilegizált munkásrétegek hatalom- és pozícióvesztése, a mezőgazdaság-ellenes agrárpolitikával iparba, városba és munkássorba kényszeritett parasztok tömegei óhatatlanul újratermelték az alattvalói tudatot.

E folyamatok közepette a munkahely felértékelödése tovább tart, stabilitást - következésképpen megélhetést - jelent, ezen túl állami ipari formái a deklarált társadalmi értékek élére kerülnek. A lakóhely szerepének visszaszorulása együtt jár a fentiekkel, különösen azokon a területeken, amely a deklarált értékrendben negativnak vagy éppen csak megtürtnek minösülnek (például kisebb települések, falvak, mezőgazdasági és határsáv-övezetek).

Az 50-es évek elsó fele óta eltelt évtizedekben jelentős gazdasági-társadalmi változásokat élhettünk meg. E változások közül - témánk szempontjából - a demokratizálódási, valamint a reformfolyamat emelkedik ki. Nézzük, mit jelentettek a lakóhely-munkahely kapcsolatában ezek a folyamatok!

Mint ismeretes, a munkaszervezetben ismételt kísérletek történtek a paternalizmus áttörésére, és egy teljesítményorientált munkakultúra kialakítására. A 60-as években a taylori munkaszervezet, a 70-es években a partneri kapcsolatok, az üzemi részvétel, az érdekérvényesítés elótérbe kerülése jellemezte munkaszervezeteinket. $\mathrm{Az}$ üzemi demokráciáról, az érdekeltség új rendszeréről, ösztönzó hatásáról, az érdekviszonyokról publikált könyvtárnyi irodalom, azt hiszem, jól jelzi a reform-törekvések ha. 
tását. Ezen a területen - ha nem is következetesen, vagy nem is az igényeinknek megfelelő módon - a korábbiakhoz képest jelentốs változások következtek be, vagy a változások ígérete került napirendre. Azaz jelentős elmozdulást és értékváltozást regisztrálhatunk.

A lakỏhelyen a fentiekkel analóg változások viszont nem következtek be. Településeink - mint ismeretes - többnyire ma is felülről is kivülről "kapják" a kommunális beruházásokat, a közműveket, az infrastruktúrát, a müvelődési házat, a víztornyot stb. A demokratizálódás e tekintetben változatlanul fáziskésésben van a munkahellyel szemben, a munkahely túlsúlya ma is döntó módon érvényesül, hiszen a munkahelyre koncentrálódik a termelés, a társadalmi-politikai részvétel, az érdekképviselet és életünk számos más tényezője. llyen körülmények között aligha túlzás, hogy a lakóhely a munkahely „munkásszállása", jelenlegi státusa legalábbis erre enged következtetni. A lakóhelyi lakossági részvétel pedig többnyire kimerül a társadalmi munkában, a településfejlesztési hozzájárulásban. Nem fejlődött ki településeink jelentős részében a lakosság "lakópolgári" státusa, munkahelyi és lakóhelyi szerepeink, magatartásunk és attitúdünk gyakran ellentmondásos.

Ezen a helyzeten szándékozik változtatni az új, 1985-ös településfejlesztési törvény, amelyet országos viták előztek meg. A törvény fontosságához, aktualitásához aligha férhet kétség, mindez azonban nem mond ellent annak, amit a lakóhely demokratizálódásának fáziskéséséról állítottunk.

\section{Helyi hatalom a gyakorlatban}

Miután vázlatosan áttekintettük a helyi hatalom "koordinátáit", mủködésének feltétel-rendszerét, nézzük, van-e egyáltalán múkődő helyi hatalom, vagy mindez csak ideáltípus, a normák, a "sollenek" - vilăga, ahogy erről GOMBÁR CSABA vélekedett: "Szerintünk ma Magyarországon lényegében - ... - helyi hatalom nincs, de lehetne és indokolt is, hogy legyen." (GOMBÁR Cs. 1983, 119. p.)

Elöljáróban idézzünk föl néhány empirikus példát a helyi hatalom múködéséről - részben saját kutatásunk területéről, részben publikált forrásokból!

Az egyik példa a ténylegesen múködő helyi hatalom hiányâra utal: a közelmúltban $X$ településen közmúvelödési intézményt létesítettek központi szándékokból és eröforrásokból. A helyi vezetés és a helyi közvélemény csak jóval a központi döntés után értesült a számukra különben kedvező fejleményről. Az eset talán legjellemzőbb mozzanata: amikor a helyi tanács végrehajtóbizottsága - mint illetékes - megvitatta, majd "döntést" hozott az ügyben, egyetlen hozzászólás, illetve kérdés hangzott el: az intézmény neve eleve eldöntött kérdés-e, illetve lehetne-e rajta változtatni.

A másik - látszólag ellentétes - példa $Y$ település gázvezeték létesítésével kapcsolatos. Miután a Valóság közölte az esetről két munkatársunk tanulmányát, a helyi vezetés első reflexe esetleges sajtóper indítás volt, majd - jellemző módon - a helyben közhasználatú inkriminált Valóság-számok "betiltása". Természetesen a sajtópertől végülis elálltak, és a betiltás sem járt eredménnyel. (OLÁH M.-VÁGVÖLGYI A. 1984, pp. 42-52.)

Hasonló példákat tömegesen lehetne fölhozni, egyfelöl a formálisan, másfelól 
az önkényesen müködő helyi hatalomra. E példák azonban - mint jeleztem - egyáltalán nem záriák ki egymást, soót, a helyi önkèny éppen azért müködhet, mert a helyi hatalom müködési módja és struktúrája túlszabályozott, deformált és igencsak távol helyesebben fölüi - áll a közérdekektól.

GOMBÁR CSABÁnak abban tehắt tökéletesen igazat kell adni, hogy a hatalmi mechanizmus egyoldalú, a helyi hatalom csak a központi akaratképzés és döntéshozatal nyúlványa, meghosszabbítása, következésképpen a kapcsolatokat minden téren csak egyetlen - és ami a legfontosabb - egyirányú csatorna közvetíti. Ugyanakkor viszont éppen ezek a játékszabályok, egyoldalúságok, túlszabályozottságok teremtenek adekvát mozgásteret a helyi hatalom tetszés szerinti müködésének. Ne feledjük, az egyetlen csatorna a központi döntésekhez való aikalmazkodás követelményén épül föl, a helyi társadalom követelményének kontrollja ebben a mozgástérben fölösleges, vagy ha felsöbb akaratból mégis szükségesnek látszik, akkor pedig illusztrativ! Márpedig heIyi kontroll hiján igencsak fölerósödhet a helyi hatalom. Ebböl a szempontból - és it nem osztom GOMBÁR véleményét - tehát nemcsak van helyi hatalom, hanem igencsak erőteljes befolyást gyakorolhat a helyi társadalom minden megnyilvánulására.

A fentiek - éppen az egyoldalúság miatt - tovább konzerválják a paternalista vezetési, irányítási gyakorlatot, amely a hatalmi grádicsok minden szintjén kialakitható. Érdemes lenne egyszer a helyi vezetők hivatalos deklarációját, szóhasználatát ebból a szempontból elemezni. Még egy példa (az építkezési rendeletek érvényesítése kapcsán): "Öt éve csodálatos városrendezési tervet készítettünk. Minden a helyén volt benne: lakótelep, ipartelep, zöldövezet, városközpont. Természetesen mindegyik övezetben hagytunk helyet a bövítésre. Itt épitési tilalom van, a többi helyen meg korlátozás, vagyis csak azt és ott lehet épiteni, ami a tervben szerepel, amit a város jóváhagyott. Volt közszemle, társadaími vita.

- A terv eikészítése óta váitoztak a viszonyok, átrendeződtek az eróforrăsok, lelassult az iparosítás, csökkentek az állami beruházások.

- Ezért adtunk új megbízást a tervezőknek, már készül az új, a mindent átfogó koncepció. Az új tervet is egyeztetjük majd mindenkivel, megvitatjuk minden fórumon, bemutatjuk a lakosságnak, és - a lakosság választott testülete - a tanácsülés fogja majd jóváhagyni.

- Mikor lehet a még el nem készült tervvel egybehangzóan most épitkezni?

- Öt-hat év múlva. A tervet jól meg kell fontolni, előzetes vizsgálatokat kell végezni - lesz vagy nyolcvan kiló a dokumentáció. És bírságolunk, ha kell, mert az állam felelösséggel tartozik polgárainak. Oka van annak, ha valahol tilalom van elrendelve: a közelben mondjuk gyár múködik, és annak a zaja, füstje egészségtelen; védösávjába valamikor erdőt telepítünk...

... Egyszerú volna szemet húnyni a lazaságok felett, de nem épithetjük el a holnap elól a lehetöségeket. Nem engedhetjük meg magunknak, hogy az áliampolgároknak csak a napi gondjaival törődjünk. A jövő nagyvárosát kell körvonalaznunk." (KULCSÁR A. 1985. 16. p.)

Mintha megrendelésre készítettük volna a tanácsi osztályvezető és a riporter párbeszédét. Túi azon, hogy azért bírságolunk, mert felelósséggel tartozunk az állampoigárokrak, meg hogy ne épitsük el a holnap elól a lehetóségeket - ugye milyen ismerósen cceng - érdemes fölfigyelni a hivatalnok merész, öntudatos, jövóre orientált 
mentalitásának és a riporter kicsinyes, a lakosság apró-csepró érdekeit (ti.: lakni akarnak valahol) firtató, földhözragadt szemléletének a kontrasztjára.

Mint ismeretes, ezek a gondok korántsem újkeletüek. Évtizedek óta súlyos tehertételként cipeljük öket. ERDEI FERENC már a Város és vidékében úgy fogalmazott, hogy bonyolult probléma a központi hatalom és a helyi önkormányzat egyensúIyának a kialakítása. Az elv világos: „Húsz éves tapasztalatunik alapján azonban fel kellett ismernünk, hogy a gyakorlat e rendszer múködése során számos súlyos problémát vet fel. Ezek egyik forrása az, hogy ugyanaz a választott szerv - a tanács végrehajtó bizottsága - egyben az önkormányzat megvalósitója is, a kỏzponti kormányzat végrehajtó szerve is. A gyakorlati tapasztalatok arra mutatnak, hogy ez a kettősség mindkét irányban zavarokat, illetöleg fennakadásokat okoz. Elkerülhetetlennek látszik a demokratikus centralizmus elve alapján és a tanácsok rendszerében a központi kormányzat és a helyi önkormányzat szerveinek valamilyen szétválasztása, kooperációjuk, illetôleg normális ütközésük tisztább és pontosabb megszervezése." (ERDEI F. 1972, 29. p.) Ehhez csak annyit fúzhetek hozzá: ERDEl szavai ma is aktuálisak. Meg talán azt, hogy ma sem sokkal egyszerübb a helyzet. Jellemzó tünet, hogy e kérdés kapcsán igen gyakran beleütközünk a központi hatalmat féltök okfejtésébe, amit talán az alábbi, mellesleg nekünk címzett mondatokkal illusztrálhatunk: "A beérett, szükséges - mi több, szükségszerü - decentralizáció mai viszonyaink között feltétlenül elörelépés, de azért nem az 'abszolút' jóság. Elönyeinek elismerése, kihasználása mellett fel kell készülnünk - és fel kell készitenünk - a várható hátrányokra is, idöben gondoskodni kell garanciákról e hátrányok ellen, nehogy a 'ló másik oldalára való átesés' már sokszor be nem vált módszerét alkalmazzuk." (BATTA P-né, JORDÁN M. 1985. 102. p.) Azt hiszem, ez sem igényel különösebb kommentárt.

Ideáltipusunk természetesen nekünk is van.

Elméietileg könnyen belátható, hogy a fent emlitett hatalmi koordinátarendszer deformációját helyre lehet állítani egyfelöl a lakóhelyi és munkahelyi részvételi és hataimi lehetőségek kiegyenlítésével, másfelól a centrum és a lokalitás partneri viszonyának kialakításával. Ez utóbbi feltétele a valóságosan müködé önkormányzat, a centrum és lokalitás sokoldalú kapcsolatrendszere. Szilárd meggyőzódésem, hogy a központi hatalom annál erősebb, minél kialakultabb, szilárdabb helyi önkormányzatokra támaszkodhat, és ellenkezóleg: helyi autonómia ês önkormányzat hiányában központi hatalma is csorbát szerived. Különben ennek a gondolatnak is évszázados tradíciója van, gondoljunk csak Eötvös szavaira:

„Szilárd aiapon nyugvó községi élet az egyedüli eszköz, mely az egyén elszigeteit állását a roppant államhatalom irányában megszünteti, anélkül, hogy az állam fönnállása veszélyeztettetnék. Ha az egyes községekben elég tért nyitunk ezer meg ezer embernek szereplésre, csak akkor várhatni, hogy derekasan megfeleljen szerepének ... Csupán önálló községek alkotása biztosíthatja az államot azon veszélyek ellen, mikkel a nép. általános törekvése, mely szerint részt akar venni a közügyek vezetésében, fenyegeti: s eszerint az egyéni szabadság védszere demokratikus államokban az államhatalom támadásai ellen ugyanaz, mely az egyéni szabadságot századokig védte egyeduralmakban az államhatalom ellen, tudnilllik; erós községek alkotása ... Ha a szabad egyesületi jogot az egyes községek körére szorítva gondoljuk is, lényeges haszonnal lenne az államra nézve, miután a szabad egyesületek fönnállása e szúk körben is csökkenti a 
községek hatalmát az egyesek fölött $s$ ezzel együtt ellenállási képességüket is az állam ellenébe ..." (EÖTVÖS J. 1981, pp. 355-356.)

Úgy gondolom, hogy a szocialista társadalmi berendezkedés, hatalmi struktúra és mechanizmus viszonyai között különösen aktuálisak Eötvös szavai. Társadalmunk további demokratizálása óhatatlanul a lakóhely és a lokalitás szerepnövelését kell hogy jelentse, amely nemcsak hatalmi egyensúlyok megteremtését eredményezheti, hanem olyan tartalékok felszabadítását is, amelyek életünk minóségét - fogalmazzunk így:állampolgári vagy lakópolgári minóségét - vál toztathatják meg.

További kérdés, hogy a településfejlesztés rendszerének megváltozása mennyiben növeli meg a lakossági részvétel jelenlegi szintjét, azaz a lakossági részvétel eddigi állapota csak a feltételek hiányának, fogyatékosságának tulajdoníthatóe? Ezzel kapcsolatban se legyenek illúzióink, megítélésem szerint napjainkban még a lakóhelyi (lakossági) részvétel még ideális feltételek esetén is - enyhén szólva - problematikus, ugyanis hiányoznak az elemi információk, nem müködik megfelelöen az érdekképviselet, és kialakulatlan a lakópolgári tudat - hogy csak a legfontosabbakat említsem.

\section{A lakossági részvétel esélyei}

A lakóhelyi információ-hiány jellegzetes példájáról egv szociográfia számolt be a közelmúltban: egy riporter állampolgári jogon részt akart venni községe tanácsülésén, amelyre mind az alkotmány, mind pedig a tanácstörvény mindnyájunkat fölhatalmaz. Szándéka riadalmat keltett a faluban, a helyi hatalom képviselői nem értették, mit akar, mi a célja, ki küldte, ki áll mögötte stb. (DIPPOLD P. 1982.) A részletek végül is - bár kétségtelenül érdekesek - kevésbé fontosak. A példa mögött álló szemlélet - az értetlenség - számunkra a legérdekesebb, ugyanis arról tanúskodik, hogy nemcsak az állampolgárok, hanem a választott vezetôk sincsenek sokszor tisztában a játék szabályokkal. Márpedig e nélkül aligha lehet demokratikus önkormányzatot kifejleszteni. (Ugyanakkor ennek a másik oldalán ott találjuk a közhatalmat játszó, ellátó, szolgáltató, javitó, karbantartó stb. intézményeket, vállalatokat - de ezek vizsgálata jelenleg nem áll szándékomban, bár kétségtelenül a helyi hatalom múködésébe is vágó jelenségről van szó.) Ilyen feltételek közt nem csodálkozhatunk azon, ha a lakossági részvétel formái és módjai többnyire lezárulnak a társadalmi munkaakcióknál és az anyagi hozzájárulásnál. Bármennyire is imponáló, hogy az ötödik ötéves tervben 20 milliárd, a hatodik ötéves terv elsó négy évében pedig 40 milliárd forint volt a településeket fejlesztõ társadaimi munka értéke (az MSZMP XIII. kongresszusának vitájában LÁZẢR GYÖRGY és POZSGAY IMRE idézte ezeket az adatokat), azt azért látnunk kell, hogy mindez nem meríti ki a részvétel tényleges tartalmát. Sőt, azt hiszem, hogy mindez in kább tekinthető egy szükséghelyzetből fakadó kényszerű áldozatvállalásnak (ti. ha a lakópolgár nem akar sárban járni, részt vesz a járdaépitésbenl, mint a lakohelyért, a lakóhelyi közösségért vállalat társadalmi-politikai cselekvésnek. E tekintetben kettös veszélyre is fölhívhatjuk a figyelmet. Az egyik abból adódhat, hogy az imponáló számokkal bármikor élénk lakossági részvételt, aktivitást lehet fölmutatni és a település közéletére is "átvinni", jóllehet kifejezetten nem erról van szó. A második veszély abban áll, hogy a lakossági anyagi és társadalmi munkát jelentő erőforrásai feltehetóen 
kimerülőben vannak, következésképpen a központi terheket nem lehet növekvő mértékben áthárítani a lakosságra. (Ne feledjük, hogy a dinamikusan növekvő társadalmi munka mellett újabb tehertételként hamarosan érvénybe lép a megnövekedett településfejlesztési hozzájárulás, amelyet az állampolgárok tekintélyes része két településre is fizethet.) Amennyiben a lakosság tehertürő képességét nem vesszük tekintetbe, az esetlegesen túlfeszített hozzájárulások minden bizonnyal a részvétel egyéb - nem materiális - formáira fognak visszaütni.

Az információkra visszatérve, egy empirikus felvételünk jó néhány kérdése a helyi informáltságra vonatkozott. (A felvételt Dabas térségében, nyolc településen végeztük, az eredmények értékelése még tart.) Adataink - bár a felmért települések között nagy a szóródás - az információs szint alacsony voltáról tanúskodnak.

A helyes válaszok szóródása az országgyúlési képviseló nevénél 7-35\%, foglalkozásánál 7-31\%, a tanácselnöknél 31-95\%, illetve 4-61\%, a tanácstag esetében $11-62 \%$, a tanácstagok szárnát tekintve $2-14 \%$. Csekély vígasz, hogy az ismeretszint - sok más jellegũ vizsgálat eredménye alapján - másutt sem jobb.

A vizsgálat során véleményt kértünk a falugyưlésrơl, s ezt egy konkrét kérdés egészítette ki: a megkérdezett részt vette a legutóbbi falugyưlésen. $12 \%$ válaszolt igennel, $88 \%$ nemmel, a szóródás pedig 6 és $15 \%$ közöttì. Az idézett adatok nem különö. sebben biztatóak. A megkérdezettek meglehetösen rosszul informáltak, közel 50\%. uknak nincs véleménye sem a tanácstagok müködéséröl, sem a falugyülésről, s csak egy kisebbség (16 illetve 25\%) tekinti fontosnak ezeket a fórumokat. (A hiányos információk természetesen elégedettséget és elégedetlenséget is okozhatnak, többnyire azonban - más felvételek tapasztalata alapján -- inkább az elégedetlenséghez szoktak hozzájárulni.)

A fenti kérdések után azt is megkérdeztük, hogy a helyi közügyek irányitásában mekkora szerepet játszanak - sorrendben - a pedagógusok, a papok, a munkások, a tanácsi vezetők, az orvosok, ügyvédek, a helyi gazdasági vezetők, az orvosok, ügyvédek, a helyi gazdasági vezetốk, a helyi pártvezetés, valamint a tsz-tagok. A felsoroltak mindegyike sajátos szempontok alapján volt fontos számunkra, s voltaképpen arra is kiváncsiak voltunk, hogy mennyíre élnek a megnevezett csoportok benne a helyi köz. életben. A válaszokat ötfokú skálán - kiemelkedő, nagy, közepes, kicsi, semmilyen szerep - mértük. A nem válaszolók aránya e kérdésben viszonylag kisebb, 15-26\% között rnozog.

A helyi közügyek irányitásában játszott szerepük alapján az alábbi sorrend alakult ki:

1. A tanácsi vezetés

2. A pártvezetés

3. A helyi gazdasági vezetők

4. Az orvosok, ügyvédek

5. A pedagógusok

6. A tsz-tagok

7. A munkások

8. A papok
103 pont

78 pont

62 pont

55 pont

20 pont

-29 pont

-40 pont

-42 pont

A rangsor - amelyet a megkérdezettek véleménye alapján készítettünk nagyjából megfelel előzetes feltételezésünknek: a tanácsi vezetés, a pártszervezet va- 
lamint a gazdasági vezetés (az egyes települések sajátosságainak megfelelö sorrendben) hatalmi súlya, befolyása s valószínúleg presztízse is messze kiemelkedik a többi közül. Némileg talán meglepő az orvosok, ügyvédek elökelö helyezése - lényegében ők is a helyi hatalmi elit tagjainak számítanak, minden valószínüség szerint tekintélyes befolyással. Ez a négy hatalmi csoport messze elkülönül az összes többitől. A pedagógusok a rangsorban is szolid szerepet játszanak, s ez a lakossági vélemény reálisnak látszik. Az persze már más kérdés, hogy a pedagógusoknak milyen szerepet kellene játszaniuk a helyi közélet formálásában. Az eddigi csoportok - a lakossági vélemények szerint - kiemelkedó vagy nagy szerepet játszanak a helyi közéletben, a következök viszont kicsit vagy semmilyent sem, s ezek sorrendben - a tsz-tagok, a munkások és a papok. Bizonyára meglepó a papok fenti megitélése, hiszen - föleg a publicisztikában és a napi propagandában - gyakran találkozunk az egyházi befolyás növekedéséről szóló információkkal. Természetesen nem tartjuk kizártnak, hogy más térségben (településeken) esetenként másfajta rangsorral találkozhatnánk, mégis, az általunk vizsgált térségben tapasztaltaknak feltételezhetően általánosabb az érvénye. Meglepetést kelthet a tsz. tagok és a munkások csekély szerepe is, mégis mindkettőt reálisnak kell tekintenünk. A munkások jelentékeny része ugyanis nem a településén dolgozó, eljáró illetve bejáró, következésképpen kevéssé van jelen a település közéletében. A tsz-tagok szerepe ennél valamivel pozitívabb - legalábbis a lakossági vélemények alapján.

$A z$ adatok értelmezéséhez hozzátartozik: vizsgálatunk várostalan térségben készült, eredményei természetesen falusi térségekre vonatkoznak. E megszoritás ellenére a fenti eredményeket mégis reálisnak tartjuk más információink és tapasztalataink alapján. A fentiek - úgy gondolom - azt is alátámasztják, hogy a lakossági részvétel határai a társadalmi munkáknál lezárulnak, s azok a lakosok - munkások, tsz-tagok és alkalmazottak - , akik járdát épitenek, iskolát, óvodát renoválnak, azaz keményen megdolgoznak a "közért”, a közéletben, a tanácsi, tanácstagi munkában, vagy akár a falugyüléseken jóval kisebb szerepet játszanak. Adataink a lakossági részvétel nem materiális formáinak, módjainak fogyatékosságáról tanúskodnak.

További tapasztalatunk az, hogy a részvétel hivatalos és spontán formái eröteljesebben divergálnak egymástól. E tekintetben sajátos jelenségnek tekinthetó, hogy miközben a részvétel hivatalos formáit a központi akarat messzemenóen támogatja, a spontán kezdeményezések többnyire nemcsak támogatás hiján maradnak, hanem esetenként riadalmat is kelthetnek. Ez utóbbi esetekben a kérdés úgy fogalmazódik meg. hogy a spontán mozgalom mennyiben veszélyezteti a formál is hatalmi struktúrák érvényesülését, jóllehet az esetek többségében nem erröl van szó. Ellenkezőleg, a spontán törekvések érvényesülése hozzájárulhat a központi hatalom legitimálásához.

A lakossági részvétel tanulmányozása kapcsán számos kérdés merül föl a kutatóban. Mindenekelött az, hogy a lakossági részvételnek milyen garanciái vannak a helyi hatalom szervezetében. Természetesen vannak ilyen garanciák, ezek azonban meg. maradnak a formális aktusoknál - szervezett társadalmi munkák, választásokon, a helyi hatalom által szervezett fórumokon való részvétel stb. A nem központi indíttatású, valóban spontán mozgalmak, törekvések, érdekek vagy akár csak kísérletek számára viszont ezek a garanciák hiányoznak. Következésképpen bármikor visszaszorithatók, fölszámolhatók, vagy nemkivánatos tényként, esetenként politikai felhanggal értelmezhe- 
tő́k. Ez a helyzet viszont eleve megnehezíti, korlátozza a különben - bármennyire paradox módon - fölülről is támogatott, spontán kezdeményezéseket.

További kérdéseket jelent, hogy a lakosság részt akare venni, részt tud-e venni, valamint érdemesnek látjae részt venni a helyi dolgok megszervezésében, irányitásában, intézésében. Az ugyanis egyáltalán nem biztos, hogy a lakosság részt akar venni a fentiekben. Nagyrészt a paternalista hatalomgyakorlás, s részben a lakossági kényelem következtében az állampolgárok tekintélyes része valószínüleg egyáltalán nem akar részt venni a döntések elökészítésében, vagy a hatalomgyakorlás szélesebb - lakosságot érintő - ügyeiben. Bizonyos fajta tehetetlenségi erőként hat az a több évtizedes beidegződésünk, hogy nemcsak leszoktunk, elszoktunk a közéleti tevékenységtől, hanem meg sem tanultuk. Illetve, amit megtanultunk, az a lakossági részvétel negatív példája: nem érdemes részt venni, mivel részvételünk eredménye enyhén szólva nem áli összhangban a befektetett energiánkkal, akár falugyúlésrơl, akár lakógyülésről vagy más ha. sonló aktusról legyen is szó. Mindez szorosan összefügg azzal, hogy az emberek tekintélyes része nem is látja érdemesnek a részvételt. Voltaképpen a paternalizmus itt üt vissza, az állampolgárok, lakópolgárok úgy érzik, hogy minden közösségi beruházást, szolgáltatást készen megkaphatnak, helyettük és felettük intézik azt úgyis el - következésképpen akár részt vesznek, akár nem, részvételük egyáltalán nem befolyásolja a településen történteket. Ez a helyzet egy sajátos kiváró mentalitást alakít ki, amellyel „passzivitás” és formalitás jár együtt. Mindehhez számítsuk hozzá azt a körülményt is, hogy az állampolgárok tekintélyes része valószínúleg akkor sem tudna részt venni, ha akarna, ugyanis nem ismeri a helyi hatalom müködésének játékszabályait, kevés az információja, nincsen tudatában állampolgári, lakópolgári jogainak.

Változást e tekintetben megint csak minden bizonnyal központi iniciatívákra lehet elképzelni, természetesen hosszabb folyamat eredményeképpen. Véleményem szerint egyáltalán nem fenyeget e tekintetben a központi hatalmat gyengító decentralizálás veszélye, vagy ahogy fentebb idéztük, nem kell félnünk a ló másik oldalára való áteséstơl, az innensỏ oldal pozíciói annyira szilárdak és tradicionálisak. Az egyensúly megteremtése azért elengedhetetlenül szükséges, hiszen csak igy folytatható - most már a lakóhely körülményei közt - az a szocialista demokratizálódás, amely a reformfolyamatok egyik fontos terepe.

Meg kell jegyeznem, hogy a lakossági részvétel bizonyos módozatai még korlátozott viszonyok közt is kialakulhatnak, müködésbe léphetnek. Elsősorban veszély. helyzet esetén. A hetvenes évek település-egvesítỏ törekvései e spontán lakossági megnyilvánulások számos szép példáját produkálták. A szociálpszichológia identitáskényszernek nevezi ezt a jelenséget, amely egy-egy közösség, csoport létének veszélyeztetésekor kerül elótérbe. Heves helyi viták, tiltakozások gyưjtése, peticiók kísérték sokszor a községegyesitést. Az utóbbi években pedig - a szabadabb mozgástér következményeképpen - számos település nyújtotta be elszakadási, önállósodási igényét. Az elöljárósági rendszer kiépítése ugyancsak az adott település identitás-tudatát, igényét növelheti meg.

Ez utóbbi példák arra utalnak, hogy bizonyos helyzetekben mégiscsak kialakulhat a lakossági részvételnek, a döntések befolyásának igénye. Kissé leegyszerúsítve úgy látom, hogy e tekintetben is kettós tendenciáról beszélhetünk: egyfelöl erősödöben van a helyi társadalom részvételének igénye, másfelöl viszont jelentős társadalmi 
rétegek (munkások, tsz-tagok) maradnak érintetlenek és érdektelenek a növekvö igény befolyásától. Úgy is fogalmazhatok, hogy az érdekérvényesitó törekvések csak egy kisebb értelmiségi-vállalkozói rétegben tapinthatók ki, a többség viszont többnyire indif. ferens ezekben a kérdésekben. Ebben a helyzetben éppen ezért döntő lehet, hogy a helyi érdekeket kik és milyen hatékonysággal tudják manifesztálni, továbbá, hogy menynyiben teremthető meg az a társadalmi nyilvánosság, amely nélkül a helyi társadalom nem funkcionálhat megfelelö módon. E tekintetben igencsak tarka településeink képe, s igencsak differenciált a lehetősége. Egyes helyeken az értelmiség és a vállalkozó szellemú irányító, szervező réteg hiánya, kivonulása kényszeríti vegetálásra a helyi társadalmat, másutt a helyi társadalom minósége (öregedó, alvó-település stb.) gátolja, akadályozza meg a kibontakozást, azaz a helyi nyilvánosság megteremtését. Viszont mintha szaporodna azoknak a településeknek a száma, amelyek sajátos módon és formákban, de mégiscsak nyilvánosságot próbálnak teremteni, helyi közéletet akarnak szervezni, s formálják a lakossági részvételt. A vállalkozások e tekintetben igen sokfélék, közéjük sorolható - hogy csak néhányat említsünk - Tiszakécske önálló, a helyi lakosság érdekeit szolgáló beruházásaival, tevékenységével, Siómaros a népfőiskolájával, Szombathely a képtárával, vagy éppen Dombóvár és Bakonyszentkirály a kalendáriumával. Végsó soron, azt hiszem, mindegy, milyen konkrét cél motiválja a lakossági részvételt, a lényeg az, hogy a legkisebb erófeszítéstöl a legnagyobbig mennyire találko. zik, esik egybe a lakosság érdekével. Van-e értelme az adott tevékenységnek, valóságos igényt fejez-e ki, vagy sem, ez a kérdés vízválasztó. Itt dől el, hogy formális lesz-e, marad-e a részvétel, hogy valóban mozgásba hozza-e a települést.

Ezek a törekvések természetesen nem maradhatnak elszigetelve a makrotársadalmi folyamatoktól. Makrotársadalmi szinten ugyanis hasonlóképpen vethetők föl a kérdések: vagy megpróbálkozunk - a reform-folyamat kiszélesitéseképpen - széles körú társadalmi nyilvánosságot teremteni, vagy pedig a gazdasági nehézségek okozta szükséghelyzetre hivatkozva korlátozzuk azt. Nem kétséges, hogy melyik módszer tekinthető hatékonynak, melyik hozhatja mozgásba a társadalom tartalékait, s melyik járul. hat hozzá minőségi változásokhoz. A helyi társadalom problémaköre e tekintetben természetszerüleg össztársadalmi szinten is kedvező változásokhoz vezethet. $A$ helyi társadalom közéletének kialakítása, nyilvánosságának megteremtése óhatatlanul hozzájárulhat a társadalom egészének demokratizálódásához is. S talán az sem utolsó szem. pont, hogy ezek a folyamatok nemcsak hogy nem veszélyeztetik a központi hatalmat. hanem elősegithetik legitimációját.

IRODALOM

BATTA P.-né-JORDÁN M. 1985: Helyi társadalmunk szerkezetéhez. Társadalmi Szemle. 40 . évf. 2. sz. pp. 102-105.

DIPPOLD P. 1982: Állampolgár voltam D-n. Szociográfia. Mozgó Világ. 4. pp. $70-75$.

ERDEI F. 1972: Város és vidéke. Szépirodalmi Könyvkiadó. Bp.

EÖTVỚ J. 1981: A XIX. század uralkodó eszméinek befolyása az államra. Eötvös József Múvei. Magyar Helikon. 355-356. illetve 388. Bp.

GOMBAR Cs. 1980: Politika clmszavakban. Politikatudományi Füzetek 1. Bp. 
GOMBÁR Cs. 1983: A helyi hatalom hermeneutikája. Hipotézisek - kutatási módszerek. Helyi társadalom I. Bp.

HANÁK P. 1982: Társadalom és politikai kultúra Magyarországon. i.m. Történelem és közgondolkodás. Kossuth Könyvkiadó. Bp.

KULCSÁR A. 1985: Épitési betyárkodás. Élet és Irodalom. Március 15.16.

KULCSÁR K. 1985: A modernizáció problémái a magyar társadalomfejliódésben. Munka, gazdaság, társadalom. Bp.

OLÁH M.-VÁGVÖLGYI A. 1984: Egy helyi döntés körülményei. Valóság. 6. pp. 42-52.

RÁNKI Gy. 1983: budapest szerepe az ország gazdasági fejißđdésében. i.m.: Mozgásterek, kényszerpályák. Elvek és utak. Magvetb. Bp. 257 illetve 278.

SZEKFU Gy. 1983: Forradalom után. Gondolat Könyvkiadó. Bp.

TÁRKÁNY SZUUCS E. 1981: Magyar jogi népszokások. Gondolat Könyvkiadó. 1981.

BÖHM, ANTAL:

\section{LOCAL GOVERNMENT AND THE PARTICIPATION OF THE POPULATION}

(Summary)

The author examines the functioning of local government in the context of workplace - residence and centre - locality and states that the centre and workplace have become predominant as a result of the specifically retarded social development in East Europe. This development took place under a similarly traditional, paternalist government which permeated both the politics of the central power and the labour organizations. The Socialist transformation of the country raised hopes for radical changes in this field but industrialization and urbanization programmes in the 1950 strengthened the central power and increased the role of the workplace. The role of the locality and residence was inevitably pushed into the background. Changes in this situation were only brought by the reform programmes of the $1960 \mathrm{~s}$, primarily within the enterprises where paternalist management carne to be replaced by modern methods of business organization. Changes in the relationship beiween centre and locality came, however, with a certain time lag as this issue has only recently been discovered as an important, so far neglected area of socialist democratization.

The changes also had an impact on several fields of settlement development, contributed to the recognition of the need for a more equitalbe distribution and the importance of population participation. It is still an open question to what extent the local government can meet the increased demands in the present conditions for functioning and through increased participation of the population. At present, local power operates in a onechannel system, with the complete absence of partnership between the centre and the locality. As to the participation of the population, it means nothing more than taking part in voluntary work for the settlement/residential area, considering that the forms and ways of participation of a higher quality have not taken shape yet. As a result of paternalist traditions citizens prefer to wait for central decisions. In this situation it is important to find out if the population is willing, or able to co-operate, if they find it worthwhile taking part in the preparation of local decisions.

In this respect there are two tendencies taking shape now; an increased demand for participation, on the one hand, and, on the other, there are still important social groups that choose to keep away from local public life. Further reform can only bring good results if locality, the place of residence can function as a ,school" preparing individuals for a democratic public life.

Ford.: Oláhné Szentessy Éva 
БËM, АHTAЛ:

\section{МЕСТНАЯ ВЛАСТЬ И ШАНСЫ УЧАСТИЯ НАСЕЛЕНИЯ}

(Резюме)

Автор статьи рассматрнвает осуществление местной власти с позиций категорий «рабочее место - место житегьства) и “центр - локальность», указывая при этом на перевес центра и рабочего места, обусловленный особенностями развития общества в Восточной Европе. Этот перевес совпал с патерналистским управлением, признаваемым традиционным и нмевщим место как в политике центральной власти, так и в трудовых организациях.

Казалось, что социалистические преобразования возьмут в корне новое направление в названной патерналистской системе, однако программа индустриализации и урбаниэзции 50-х годов укрепила цөнтральнуо власть и өще больше повысила значөние рабочего места, что привело к неизбөжному отступлению на задний план роли локальности и мөста жительства. Иэменення в создавшемся положении наступили только в 60-8 годы после прннятия программы рөформы и касапись в перву о очөредь заводской сферы, где начала происходить замена патерналистского управления современным способами организации пронзводства. Что же касается сдвига в отношениях между категориями центр и локальность, го здесь наблюдается расхождение по фазе: зтот круг өопросов только в последние годы встап на повестку дня как важная - и до сих пор малонспопьзованная - область социалистичөской дөмократизации.

Изменения затронули многочмсленные сферы развития н планирования поселений, проблему болея справедливог, распределения ресурсов развития и вопрос растущего значения участия населения в управлении. Но сможет пи местная власть при существующих условиях функционирования и более активном участии населениз удовлетворить возрастающие потребности? Местная власть сегодня имеет чаще всего «один канал», ей не хватает партнерской всязи между центром и локапьностью, участие же в ее осуществлении населения исчерпывается обычно общ;ественной работой на местах, не поднимаясь до высот качественного прнобщения. Патерналистские традиции выработали в гражданах некий «выжидающий» складума: все ожидается от центрапьных решений. Желают ли, могут ли граждане принимать участие в подготовке местных рецений, счнтают ли зто участие целесообразным? Это очень важный вопрос в данной ситуацин.

Зышензложенное харахтеризуют две тенденции: с одной стороны, растет потребность в приобщения населения к өласти, с другой стороны, љначигельная часть общестөа все еще стоит в стороне от общественной жизни, а ведь дальнвйшие реформы будут иметь успех только в том случае, если локальность и место жительства станут предаверьем демократичоской жизни в об̆цестве.

Forditotica: dr. Molnár Lászíbrié 